原 著

椎骨脳底動脈循環不全によるめまい症例の赤血球変形能

長場章

\title{
Measurement of Red Blood Cell Deformability in Patients with Vertigo due to Vertebro-basilar Insufficiency
}

\author{
Akira Nagaba \\ Department of Otorhinolaryngology, Niigata University School of Medicine
}

Hemorheological impairment is thought to be one of the pathological conditions of vertebro-basilar insufficiency (VBI). To determine the contribution of impaired red blood cell deformability (RCD), one of the important factors of hemorheological impairment, to the pathogenesis of VBI, RCD was measured and compared between a group of VBI patients (21 males, 42 females) and a group of control adults without vertigo (22 males, 23 females). Diagnosis of VBI was based on the Guidelines established by the Japan Society for Equilibrium Research. RCD was measured by the red blood cell (RBC) centrifugation method according to the criteria established by the International Committee for Standardization in Haematology. RCD was significantly decreased in the VBI group $(\mathrm{p}<0.01)$. Blood levels of total cholesterol and triglyceride in the VBI group were significantly higher than those in the control group $(\mathrm{p}<0.05)$. RCD was not correlated with $\mathrm{RBC}$ counts, $\mathrm{Hb}, \mathrm{Ht}, \mathrm{MCV}, \mathrm{MCHC}$, platelet count or total cholesterol or triglyceride level. Administration of dilazep dihydrochloride (300 mg/day for 8 weeks) to VBI patients induced significant $(\mathrm{p}<0.05)$ improvement in RCD and relieved vertiginous symptoms. Vertigo in VBI is considered to result from a combination of conditions involving microcirculation disorder induced by decreased RCD, decreased vertebral arterial blood flow due to high blood levels of total cholesterol and triglyceride, and rapid occurrence of right-left difference in blood flow by action stimulation.

Key words: red blood cell deformability, vertebro-basilar insufficiency, centrifugation method

\section{はじめに}

めまいの原因は多岐にわたるが，中枢性機能性 めまいの代表的な原因のひとつに椎骨脳底動脈循 環不全 (vertebro-basilar insufficiency; 以下 VBI) があげられる。これは一過性脳虚血発作の一種 で, 椎骨脳底動脈領域の血流量の一過性減少が原

新潟大学医学部耳鼻咽喉科学教室
因と推定される1)。最近，VBI には血管の屈曲， 蛇行, 狭窄などの血管走行, すなわち血管力学的 な異常が原因で発症する症例の他に，血圧や血小 板凝集能などの血液レオロジ一因子の異常が絡み 合って発症する症例のあることがわかってきた2）。 そこで, VBI が原因と思われるめまい患者につ いて赤血球变形能を中心とした血液レオロジー因 子の関与について検討を加觉た。 


\section{対象と方法}

\section{1. 対象}

VBI の診断は, 日本平衡神経科学会によるめ まい診断の基準化の資料1）を参考にし自家考案し た診断基準を満たし（表 1)，強くVBI が疑われ たものとした。対象は，1993年 6 月より1995年 7 月までに新潟大学医学部耳鼻咽喉科を受診した $\mathrm{VBI}$ 症例のらち, 赤血球変形能などの血液レオ ロジー因子の検討が可能であった63例（男性 21 例, 女性 42 例, 33 78歳, 中央值59.4歳) でこれ をVBI 群とした。な执, 対照群はめまいやVBI を示唆する症状がなく, 検査の内容を説明し同意 の得られた成人 45 例（男性 22 例, 女性23例, 18〜 71 歳, 中央値 46.6 歳) である。

2. 検査ならびに方法

1) 病歴

VBI 群の病歴をめまいの性状, 発症の状況, 持続時間, 随伴症状, 既往歴などにわけ検討し た。

2 ) 眼振検査抢よびシェロングテスト

VBI 群全例に ENG 記録による眼振検査を施行 した。すなわち自発・注視・頭位眼振検查, 温度 刺激検査, 回転刺激検査, 追跡眼球運動検查 (Eye Tracking Test; ETT), 視運動性眼振 (Optokinetic Nystagmus; OKN) 検査である。またシェ ロングテストも全例に施行した。

3 ) 赤血球変形能

赤血球変形能の測定には, 赤血球濾過法の一種 である赤血球遠心法3)4 を用いた。これは採血 後, 2 時間以内に全血 $20 \mu \mathrm{l}$ を緩衝液（東亜医科

\section{表 1 VBI の診断基準}

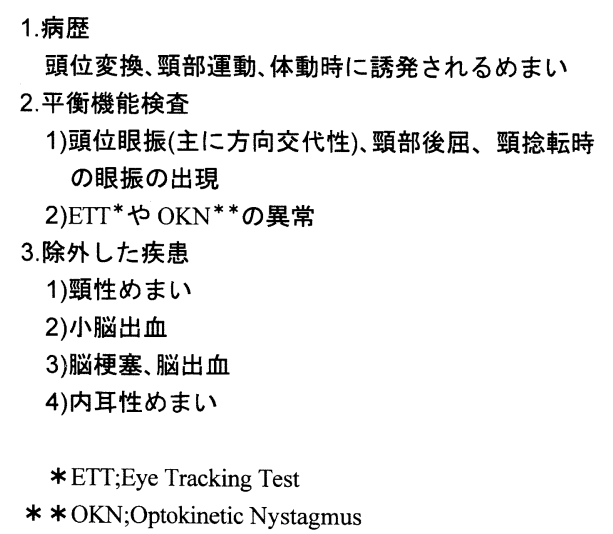

機械製セルパックTM) $10 \mathrm{ml}$ で500倍に希釈した のち $5 \mu 1$ のフィルターを持つ遠心濾過チューブ (日本ミリポア社製ウルトラフリーC $3 \mathrm{SV}^{\mathrm{TM}}$ ) に て150 G，5 分間遠心するが，その際遠心前後の検 体から $100 \mu 1$ を採取後さらに緩衝液 $10 \mathrm{ml}$ で希 釈し，それぞれの赤血球数を自動血球計算機で求 め, その濾過率で赤血球変形能を表す方法であ る。VBI 群と対照群の赤血球変形能を測定し, 両群間での比較を行った。

4 ）末梢血液検査, 総コレステロール，トリグ リセリド

末梢血液検査のらち, 赤血球数, 血色素量, 一 マトクリット值, 平均赤血球容積 $(\mathrm{MCV})$, 平均 赤血球血色素濃度 $(\mathrm{MCHC})$, 血小板数と総コレ ステロール，トリグリセリドを測定し，VBI 群 と対照群の間で比較検討した。また, VBI 群に ついては, 赤血球变形能と末梢血液検査, 総コレ ステロール，トリグリセリドとの相関も検討し た。

5 ) 塩酸ジラゼプの効果

VBI 群のうち, 虚血性心疾患・脳血管障害治 療剤である塩酸ジラゼプを投与した11例について 投与前, 投与後の 8 週の赤血球变形能とめまい症 状の自覚的改善度を比較した。な拉, めまい症状 の自覚的改善度は, 山口ら5) の判定基準を参考 に, め末いの著明改善, 改善, やや改善, 不変, 悪化の 5 段階で判定した。

有意差の判定には両側検定によるWilcoxon 検 定，Mann-Whitney U 検定を用いた。

\section{結果}

1. 病歴 (表 2)

VBI 群に打けるめまいの性状は, 回転性が43 例 (68.2\%) と最も多く, 浮動感19例 (30.2\%), 眼前暗黒感 1 例 (1.6\%) であった。め屯い発症 時の状況は朝の起床時（臥位から座位）が27例 (42.9\%) と最も多く, ついで頭位変換時が 11 例 (17.5\%), 体動時が 9 例 (14.3\%) であった。こ れを頸部捻転時, 起立時など何らかの体動に伴っ て発症したものとそらでないものとに分けると前 者53例 $(84.2 \%)$ に対し体動とは全く関係のない 後者は10例（15.8\%）になる。めまいの持続時間 は数時間以上が 23 例 $(36.5 \%)$ に対し数十分以内 が40例（63.5\%） と比較的短い例が多い傾向にあ った。随伴症状は悪心, 嘔吐が33例 (52.4\%) と 
表 2 めまいの病歴

\begin{tabular}{|c|c|c|}
\hline & & 例数(\%) \\
\hline \multirow[t]{3}{*}{ めまいの性状 } & 回転性 & $43(68.2)$ \\
\hline & 浮動感 & $19(30.2)$ \\
\hline & 眼前暗黒感 & $1(1.6)$ \\
\hline \multirow[t]{9}{*}{ 発症の状況 } & 朝起床時 & $27(42.9)$ \\
\hline & 頭位変換 & $11(17.5)$ \\
\hline & 体動時 & $9(14.3)$ \\
\hline & 頸部捻転時 & $5(7.9)$ \\
\hline & 起立時 & $1(1.6)$ \\
\hline & 立位時 & $4(6.3)$ \\
\hline & 安静時 & $4(6.3)$ \\
\hline & 覚醒時自発 & $1(1.6)$ \\
\hline & 自動車運転時 & $1(1.6)$ \\
\hline \multirow[t]{5}{*}{ めまいの持続時間 } & 数秒 & $13(20.6)$ \\
\hline & 数分 & $19(30.2)$ \\
\hline & 数十分 & $8(12.7)$ \\
\hline & 数時間 & $21(33.3)$ \\
\hline & 一日以上 & $2(3.2)$ \\
\hline \multirow{6}{*}{$\begin{array}{l}\text { 随伴症状 } \\
\text { (重複あり) }\end{array}$} & 悪心、嘔吐 & $33(52.4)$ \\
\hline & 肩凝り & $6(9.5)$ \\
\hline & 頭重感 & $6(9.5)$ \\
\hline & 蛤牛症状 & $3(4.8)$ \\
\hline & 手のしびれ & $2(3.2)$ \\
\hline & なし & $18(28.6)$ \\
\hline \multirow[t]{5}{*}{ 既往歴 } & 高血圧 & $11(17.5)$ \\
\hline & 糖尿病 & $3(4.8)$ \\
\hline & 脳梗塞 * & $3(4.8)$ \\
\hline & 低血圧 & $2(3.2)$ \\
\hline & 心筋梗塞 & $1(1.6)$ \\
\hline \multicolumn{3}{|c|}{$\begin{array}{l}\text { *陳旧性のテント上脳梗塞で、めまいと関連が } \\
\text { ないと判断された症例 }\end{array}$} \\
\hline
\end{tabular}

半数以上にみられ，他に肩凝り，頭重感がそれぞ れ6例 $(9.5 \%$ ) であった。

既往歴では高血圧11例（17.5\%）, 軽度の糖尿 病 3 例 $(4.8 \%)$, 脳梗塞（陳旧性のテント上脳梗 塞で，めまいと関連がないと判断された症例） 3 例 $(4.8 \%)$, 低血圧 2 例 $(3.2 \%)$, 心管梗塞 1 例 (1.6\%) がみられた。

2. 眼振検查（表 3 ）拉よびシェロングテスト 中枢性障害が疑われる眼振検查所見について検 討した結果, 頭位眼振では方向交代性眼振が 8 例 (12.7\%), 頸部後屈, 頸部捻転に伴う眼振が 9 例 (14.3\%) にみられた。眼運動系の検査では，水 平ETTに执いて saccadic pursuit が12例（19.0 \%)に，また ataxic pursuit が 1 例 $(1.6 \%)$ に みられた。垂直 ETT では saccadic pursuit が20 例 (31.7\%) に，また ataxic pursuit が 7 例 (11.1
表 3 VBI 群の眼振検査

\begin{tabular}{l|r}
\multicolumn{1}{c}{} & $\begin{array}{c}\text { (重複あり } \\
\text { 例数 }(\%)\end{array}$ \\
\hline 方向交代性眼振(+) & $8(12.7)$ \\
頸部誘発眼振(+) & $9(14.3)$ \\
水平ETT:saccadic pursuit & $12(19.0)$ \\
水平ETT:ataxic pursuit & $1(1.6)$ \\
垂直ETT:saccadic pursuit & $20(31.7)$ \\
垂直ETT:ataxic pursuit & $7(11.1)$ \\
水平OKN抑制 & $22(34.9)$ \\
垂直OKN抑制 & $32(50.8)$ \\
異常なし & $8(12.7)$
\end{tabular}

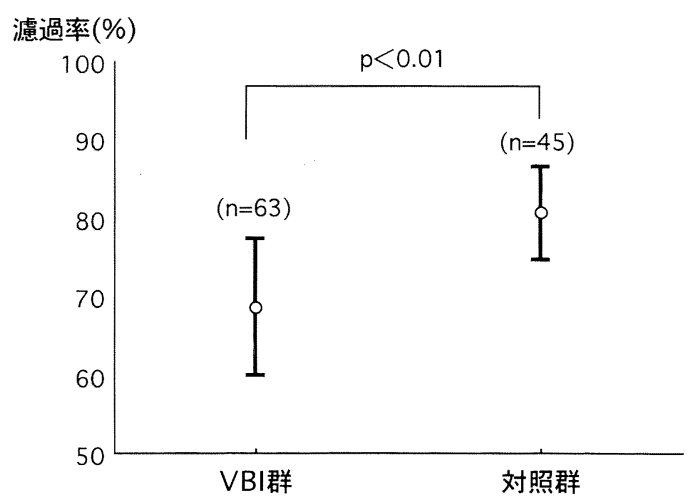

図 1 赤血球変形能

VBI 群の赤血球変形能（濾過率）は, 対 照群と比較して有意に低下していた。

\%）にみられた。OKN の解発抑制は水平方向で は22例 $(34.9 \%)$ ， また垂直方向では32例 （50.8\%）にみられた。

シェロングテストでは16例（25.4\%）が陽性で あった。

3 . 赤血球変形能 (図 1 )

VBI 群63例の赤血球濾過率平均 $68.6 \pm 8.7 \%$ に対し対照群45例のそれは $80.6 \pm 5.9 \%$ であっ た。VBI 群の赤血球濾過率, すなわち赤血球変 形能は対照群と比べて有意に低下していた（ $\mathrm{p}<$ $0.01)$ 。

4. 未梢血液検査, 総コレステロール，トリグ リセリド（表 4 ）

赤血球数ならびそ血色素量, ヘマトクリット值 はVBI 群と対照群の間に差がなかった。 MCV はVBI 群が対照群に比べて有意に大きかったが $(p<0.05), M C H C$ では差を認めなかった。血小 
Equilibrium Res Vol. 57(5)

表 4 血液学的検查結果

\begin{tabular}{|c|c|c|c|}
\hline 血液因子 & VBI群 & 対照群 & 両群の比較 \\
\hline 赤血球数 $\left(\times 10^{4} \mathrm{~mm}\right)$ & $442 \pm 42$ & $460 \pm 52$ & 有意差なし \\
\hline 血色素量 $(g / d l)$ & $13.8 \pm 1.4$ & $13.5 \pm 2.0$ & 有意差なし \\
\hline ヘマトクリット値(\%) & $41.0 \pm 3.6$ & $40.9 \pm 4.9$ & 有意差なし \\
\hline $\operatorname{MCV}(\mathrm{fl})$ & $92.7 \pm 3.5$ & $89.1 \pm 7.3$ & $p<0.05$ \\
\hline $\mathrm{MCHC}(\%)$ & $33.7 \pm 1.0$ & $33.1 \pm 1.3$ & 有意差なし \\
\hline 血小板数 $\left(\times 10^{4} \mathrm{~mm}\right)$ & $23.4 \pm 4.8$ & $26.2 \pm 5.2$ & $p<0.05$ \\
\hline 総コレステロール $(\mathrm{mg} / \mathrm{dl})$ & $214 \pm 32$ & $191 \pm 41$ & $p<0.05$ \\
\hline \multirow[t]{2}{*}{ トリグリセリド( $\mathrm{mg} / \mathrm{dl})$} & $148 \pm 86$ & $99 \pm 47$ & $\mathrm{p}<0.05$ \\
\hline & & (平均 $\pm \mathrm{SD}$ ) & \\
\hline
\end{tabular}

表 5 赤血球变形能と各血液因子の相関

\begin{tabular}{l|c|c} 
& 相関係数 & $P$ 値 \\
\hline 赤血球数 & -0.041 & 0.7507 \\
血色素量 & -0.033 & 0.8017 \\
ヘマトクリット値 & -0.071 & 0.5825 \\
MCV & -0.092 & 0.4769 \\
MCHC & 0.049 & 0.7083 \\
血小板数 & -0.061 & 0.6445 \\
総コレステロール & 0.176 & 0.1707 \\
トリグリセリド & 0.021 & 0.8742
\end{tabular}

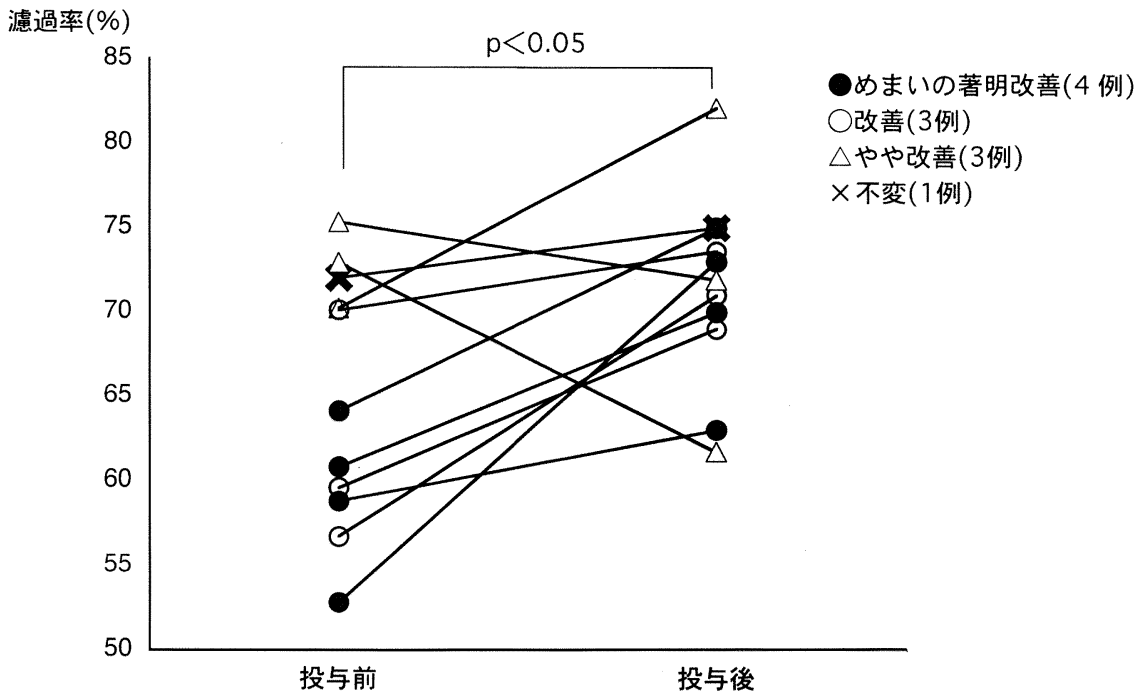

図 2 薬剤投与に上る赤血球変形能の変化

板数は対照群の方が有意に多かった（p<0.05）。 総コレステロールとトリグリセリドの值は, VBI 群が対照群に比べて有意に高かった $(\mathrm{p}<0.05)$ 。

5 . 赤血球変形能と末梢血液検査, 総コレステ

\section{ロール，トリグリセリドとの相関（表 5 ）}

VBI 群の赤血球変形能と末梢血液検査, 総 レステロール，トリグリセリドとの相関を検討し たが，いずれの因子とも相関はみられなかった。 
6. 塩酸ジラゼプの効果 (図 2 )

塩酸ジラゼプを投与した VBI 11例のらち, め まい症状の自覚的改善度は, めまいの著明改善が 4 例 $(36.4 \%)$, 改善が 3 例 $(27.3 \%)$ あり, 計 7 例 (63.7\%) が改善以上であった。これら改善 以上の 7 例では塩酸ジラゼプ投与により全例赤血 球変形能も改善した。全体では11例中 9 例 $(81.8$ $\%$ ）に，薬剂投与による有意な赤血球変形能の改 善がみられた $(\mathrm{p}<0.05)$ 。な和めまい症状が悪 化した症例はなかった。

\section{考察}

中枢性めまいの原因は多岐にわたるが，中枢性 機能性めまいの原因として VBI はきわめて重要 と考元られる。当科に执ける中枢性機能性めまい の疾患別頻度では脳循環障害が最も多く, 中でも 椎骨脳底動脈系の障害とめまいとの関係が深い6)。 これに対し器質的な血管病変が同定される中枢性 めまい症例277) は思ったより少ないため, 画像検 査とともに病歴, 眼振検査, 血液学的検査が重要 となる。当科に扣ける VBI 症例の特徵として, 病歴では汇とんどの症例で頸捻転, 起立時などの 体動に伴いめまいが発症していた。また眼振検査 では，中川ら8）の報告と同様に OKN の異常が見 られる症例が多くを占めた。一方, 血液自体にお ける循環障害の原因としては, 貧血など酸素運搬 に関わる因子のほかに血流に影響を与える因子が あり，これを血液レオロジー因子と呼ぶ。具体的 には血小板凝集能, 血液粘度, ヘマトクリット, 赤血球変形能, 赤血球凝集能, 血漿粘度, 白血球 変形能などがあげられる910)。このらち血小板凝 集能とめまいについて加藤ら ${ }^{11)}$ は, メニエール 病, めまい症では血小板凝集能の立進による微小 循環障害が, めまいの発症に関与していると述べ ている。今回われわれは血小板凝集能以外の因子 として赤血球変形能に注目し, 検討を加えた。さ らに，血液レオロジー因子の改善を目的とした治 療が VBI によるめまいにも有用かどらかを検討 した。

赤血球変形能とは, 赤血球（直径 $7 \mu \mathrm{m}$ ) が微 小な血管（内径 3〜 $5 \mu \mathrm{m}$ ）を通過する際に，その 形態を変形させる能力をいら 12$)$ 。赤血球変形能の 低下は糖尿病 ${ }^{13)}$, 末梢動脈閉塞疾患 ${ }^{14)}$, 妊娠中毒 症 $^{15)}$ などで認められて打り, この変形能の低下 が, 逆にこれらの疾患の微小循環障害を増悪させ
るといわれる。

赤血球変形能の測定方法としては, 赤血球濾過 法が一般的な方法とされているが4)，今回はとの 一種である赤血球遠心法を用いた。本法は，(1)全 血を用いるため, 赤血球浮遊液を作製する必要が なく，簡便で検体の損傷が少ない，(2)全血を利用 すると, 赤血球変形能の測定值に血漿成分が影響 を及ぼすことがあるが，全血を大量の緩衝液で希 釈することで影響を薄くしている，(3)遠心濾過チ ューブ以外に特別な器具を必要としないなどの利 点がある ${ }^{3)}$ 。

今回の検討では, VBI 群の赤血球変形能は対 照群に比べて有意に低下していた。一方，へマト クリット值は対照群と差はなかった。また，VBI 群の総コレステロールとトリグリセリドは対照群 に比べて有意に高値であった。山中ら ${ }^{16)}$ は, 総 コレステロールやトリグリセリドが高值を示す症 例では, 椎骨動脈の血流速度が低下すると報告し ている。すなわち, VBI によるめまいは, 血管 走行などの形態的異常がみられなくとも, 赤血球 変形能の低下をはじめとした血液レオロジー因子 の異常による微小循環障害に, 総コレステロー ル，トリグリセリドの高值による椎骨動脈血流の 低下が加わり，さらに頸捻転や体動などの動作刺 激によって急激に血流の左右差が生じ，めまいが 誘発されるのではないかと考兄られた。

赤血球変形能は(1)赤血球内部粘度（へモグロビ ン濃度に依存), (2)赤血球膜の性状, (3)赤血球の 形態によって規定されるといわれる12)。VBI 群の 血液所見をみると, 赤血球数, 血色素量は正常範 囲内であり, MCV は対照群より高值を示したも のの赤血球变形能との相関がなく，また赤血球の 形態異常を起こすような基礎疾患も含まれていな かった。従って赤血球変形能の低下は赤血球膜性 状の異常によって起こったものと考兄られる。赤 血球膜性状の異常の原因として澤村17) は赤血球 膜脂質のコレステロールおよびュレステロール／ リン脂質比の増大を, 織田ら ${ }^{18)}$ は血中総コレス テロール值の高值を, 工藤ら ${ }^{13)}$ は HDL コレス テロール值の低下をそれぞれあげている。今回の 検討では VBI 群の総コレステロール值は対照群 より高值であるものの, 赤血球変形能との相関を 得るには至らなかったため, 赤血球膜性状の異常 の原因については今後の検討が必要である。 
赤血球変形能を改善させる薬剤として塩酸ジラ ゼプを使用したが，本剤は赤血球形態の維持と変 形能の充進のほかに脳動脈血流量の改善や血小板 凝集抑制などの作用がある19) 21)。今回投与した 症例のららめまい症状の自覚的改善度が改善以上 を示した 7 例は赤血球変形能も改善して扣り, 脳 動脈血流量改善や血小板凝集抑制などの効果とと もに赤血球変形能の改善が臨床症状の改善に貢献 したものと思われた。以上のことから，VBI は 赤血球変形能などの血液レオロジー因子をはじめ として血圧, 血行, 血流などの様々な因子が絡み 合って発症しているものと考光られた。

\section{まとめ}

1.VBI 症例に対してめまいの病歴, 眼振検 査, シェロングテストについて検討し, 血液レオ ロジー因子については赤血球変形能とへマトクリ ット值, さらに総コレステロール, トリグリセリ ドの測定を行い(VBI 群), これをめまいやVBI を示唆する所見のない成人（対照群）と比較検討 した。

2. VBI 群の赤血球変形能は, 対照群に比べ て有意に低下していた。

3.VBI 群の総コレステロール，トリグリセ リドは, 対照群と比較して有意に高值であった。

4.VBI によるめまいは, 赤血球変形能の低 下による微小循環障害に, 総コレステロール, ト リグリセリドの高值による椎骨動脈血流の低下が 加わり, さらに頭位変換や体動などの動作刺激に よって急激に血流の左右差が生じて発症するもの と思われた。

5. 赤血球変形能を改善させる塩酸ジラゼプを VBI 群の11例に投与したところ，9 例は有意に赤 血球変形能が改善し, そのらち 7 例はめまいが消 失または改善した。

6. VBI は, 赤血球変形能などの血液レオ口 ジー因子をはじめとして，血圧，血行，血流など の様々な因子が絡み合って発症するものと考光ら れた。

稿を終えるに臨み, 御指導御校閲を賜わった恩 師中野雄一名誉教授に深甚なる謝意を捧げます。 また直接御指導いただいた五十嵐秀一前助教授, 野々村直文助教授, 川名正博講師, ならびに赤血 球遠心法による測定について御教示いただいた本
学検査診断学教室, 岡田正彦教授に深 $く$ 感謝致し ます。

この論文の要旨は第52回, 第53回, 第54回日本 平衡神経科学会総会にて発表した。

\section{文献}

1 ） 1987年めまいの診断基準化委員会答申書 : め まいの診断基準化のための資料. Equilibrium Res 47: 267-268, 1988

2 ）松永 喬：椎骨脳底動脈循環動態とめまい。 第96回日本耳鼻咽喉科学会総会宿題報告別刷 (千葉市)。100-102頁, 1995

3 ) Okada M, Matsuto T, Sugita O, et al: A simple method to measure red blood cell deformability by centrifugation. Presse Med 12: 1613-1615, 1994

4 ) International Committee for Standardization in Heamatology: Guidelines for Measurement of Blood Viscosity and Erythrocyte Deformability. Clin Hemorheol 6: 439-453, 1986

5 ) 山口秀樹, 木村 化, 伊藤真郎, 他 : めまい に対するコメリアン・アデホス併用治療の有 用性の検討. 耳鼻展望 35 補 $2: 107-116,1992$

6 ) 中野雄一：耳鼻咽喉科講義ノ一ト。122-124 頁, 考古堂書店, 新潟, 1997

7 ) Rieger P, Lischewski R, Sindermann F: Schwindel und Vertebraliseingung. HNO 27: 91-95, 1979

8 ) 中川 肇, 水越鉄理, 渡辺行雄, 他 : 脳血管 障害例の平衡機能検査所見（第一報）椎骨動 脈異常症例について. Equilibrium Res 48: 132-137, 1989

9 ) 棚橋紀夫 : 脳血管障害一へモレオロジカルな 側面を中心に一。診断と治療 81：674-680, 1993

10）浜野均, 篠原幸人: 脳血管障害慢性期の臨 床 4 病態一血液レオロジーの面から. 日医師 会誌 118 No. 8: 10-12, 1997

11）加藤 功, 朝倉美弥: め屯い症例の血小板凝 集能.耳鼻臨床 90: 975-980, 1997

12）山口 寛, 古川欽一: 赤血球変形能. 現代医 療 23: 295-298, 1991

13）工藤幹彦, 掛橋健一, 土屋寛子 : 糖尿病患者 の赤血球変形能. 青森中病医誌 37: 245-249, 
1992

14）山口 寛, 土田博光, 清水 隆, 他: 末梢動 脈閉塞疾患に扣ける赤血球变形能と ticlopidine の効果及び細粒剤の使用経験. 循環器 22: 97-103, 1987

15）光井行輝 : 電子スピン共鳴法による赤血球变 形能の測定およびその意義に関する研究. 日 産婦会誌 43: 157-164, 1991

16）山中敏彰, 藤田信哉, 上田隆志, 他 : 椎骨動 脈血流動態と血圧, 脂質値との関係. 耳鼻 39: 811-816, 1993

17）澤村俊比古：慢性閉塞性動脈疾患の赤血球変 形能と膜脂質に関する研究. 日外会誌 85 : 378-391, 1984

18）織田真智子, 阿部博子, 有地 滋: 赤血球変 形能に対する桂枝伏苓散の作用. 和漢医薬会
誌 1: 243-248, 1984

19）安永幸二郎, 神崎光也, 木村征夫 : Dilazep dihydrochloride の血小板凝集抑制作用. 内 科宝函 27: 99-107, 1980

20）葛谷文男：Dilazep の赤血球に及ぼす影響 （第 1 報）一Dilazep の赤血球変形能に及涪 す影響（in vivo）一。 基礎と臨 12: 1949-1952, 1978

21）葛谷文男 : Dilazep の脳血流量に及ぼす影響 （第 2 報）一健常者を用いた超音波ドプラー 法による量反応の比較検討一。診療と新薬 18: 1635-1649, 1981

$\left(\begin{array}{l}\text { 原稿到着 : 平成10年 } 3 \text { 月 } 11 \text { 日 } \\ \text { 別刷請求先 : 長場 章 } \\ \text { 个951-8510 新潟市旭町通1-757 } \\ \text { 新潟大学医学部耳鼻咽喉科学教室 }\end{array}\right)$

